\title{
Bovine milk antioxidant properties: effect of in vitro digestion and identification of antioxidant compounds
}

\author{
Davide Tagliazucchi $^{1} \cdot$ Ahmed Helal $^{1,2}$. \\ Elena Verzelloni ${ }^{1} \cdot$ Angela Conte $^{1}$
}

Received: 1 February 2016 / Revised: 26 May 2016 / Accepted: 27 May 2016 /

Published online: 13 June 2016

C) INRA and Springer-Verlag France 2016

\begin{abstract}
Milk proteins contained encrypted in their sequence biologically active components that can be released by enzymatic hydrolysis. Among the biological activities recognized in milk components, the antioxidant activity is of great interest. The objective of the present study was to analyse the antioxidant properties of whole, semi-skimmed and skimmed milk during simulated gastrointestinal digestion and to identify the compounds responsible for the antioxidant activity. Simulated digestion increased the 2,2'-azino-bis(3-ethylbenzothiazoline-6-sulphonic acid (ABTS) ${ }^{+}$radical scavenging activity of milk. In digested whole milk, the main contribution to $\mathrm{ABTS}^{+}$ radical scavenging activity was due to high molecular weight fraction $\left(>3 \mathrm{~kg} \cdot \mathrm{mol}^{-1}\right)$. For semi-skimmed and skimmed milk, the main contribution was due to low molecular weight fraction $\left(<3 \mathrm{~kg} \cdot \mathrm{mol}^{-1}\right)$. Twelve major peaks were collected from low molecular weight fraction of digested skimmed milk by reversed-phase high-performance liquid chromatography and evaluated for their $\mathrm{ABTS}^{+}$radical scavenging activity. Among the different fractions, three (F2, F3 and F5) showed high $\mathrm{ABTS}^{+}$and hydroxyl radical scavenging activity and lipid peroxidation inhibitory capacity. The compounds (free amino acids and peptides) present in these fractions were identified with nano-LCQTOF MS/MS analysis. The amino acids tryptophan and tyrosine seemed fundamental in the $\mathrm{ABTS}^{+}$and hydroxyl radical scavenging capacities whereas the amino acids phenylalanine and histidine played an important role in the lipid peroxidation inhibitory activity of the peptides. The results reported in this study suggested that milk proteins
\end{abstract}

Davide Tagliazucchi and Ahmed Helal equally contributed to this work

Davide Tagliazucchi

davide.tagliazucchi@unimore.it

1 Department of Life Sciences, University of Modena and Reggio Emilia, Via Amendola, 2-Pad. Besta, 42100 Reggio Emilia, Italy

2 Department of Food and Dairy Sciences and Technology, Damanhour University, Damanhour 22516, Egypt 
could act as a carrier for the delivery of antioxidant compounds in the gastrointestinal tract possibly protecting the gastrointestinal tract itself from the oxidative damage.

Keywords In vitro gastrointestinal digestion - Antioxidant activity · Mass spectrometry · Peptides $\cdot$ Aromatic amino acids

\section{Introduction}

Antioxidant compounds are considered important for human health, thanks to their ability to scavenge free radicals and contribute to prevent chronic diseases, such as cancers, coronary heart diseases and neurodegenerative disorders (Del Rio et al. 2013). Dairy products showed antioxidant activity and have been considered as important dietary components that contribute to the total intake of antioxidants. In milk, proteins (especially caseins) are the most important radical scavenger compounds (Clausen et al. 2009).

Most bovine milk proteins, mainly $\beta$-lactoglobulin and $\alpha_{\mathrm{S} 1 \text {-casein, are also potential }}$ allergens, and cow's milk protein allergy is the most prevalent in infancy, reaching an incidence of about 2 to $7.5 \%$ (Bu et al. 2013). Reduction of milk protein allergenicity by technological processing such as heat treatment, lactic fermentation and enzymatic hydrolysis is a topic of major relevance to develop hypoallergenic milk products $(\mathrm{Bu}$ et al. 2013).

Enzymatic hydrolysis is an effective means to generate bioactive peptides from intact protein sequences (Pihlanto 2006). The biological activities of these peptides include antimicrobial, antihypertensive, antithrombotic and antioxidative activities (Pihlanto 2006; Power-Grant et al. 2013). Antioxidant peptides and amino acids are particularly interesting for their possible contribution to health promotion and disease prevention (Power-Grant et al. 2013).

The composition and the biological properties of the peptides contained in milk hydrolysates depend on the substrate, the proteolytic enzymes, the enzyme-to-substrate ratio and physicochemical conditions ( $\mathrm{pH}$, hydrolysis time and temperature of reaction) (del Mar Contreras et al. 2011). A variety of proteolytic enzymes has been used to generate milk protein hydrolysates with different degrees of hydrolysis, containing a diverse assortment of peptides and different antioxidant activity. Digestive enzymes and combinations of different proteinases such as alcalase and thermolysin have been utilized to successfully generate antioxidant peptides from various milk proteins (Pihlanto 2006; Power-Grant et al. 2013). For example, a peptic digest of bovine caseins produced the $\alpha_{\mathrm{S} 1}$-casein-derived peptide YFYPEL with a strong superoxide anion scavenging activity (Suetsuna et al. 2000). One potent antioxidant peptide (WYSLAMAASDI) was purified from bovine $\beta$-lactoglobulin hydrolysed with Corolase PP (Hernández-Ledesma et al. 2005). Thermolysin was utilized to generate two antioxidant peptides (LQKW and LDTDYKK) from $\beta$-lactoglobulin (del Mar Contreras et al. 2011).

Milk proteins are deeply transformed in the human gastrointestinal tract because of the presence of different proteases. Peptides generated in the gastrointestinal tract may have different biological properties, such as antimicrobial, antioxidant and antihypertensive. (Boutrou et al. 2015). However, until now, little studies have been carried on 
the production of antioxidant compounds during the in vitro digestion of milk proteins and, above all, the nature of bioactive antioxidant compounds released during digestion has not been revealed. In vitro gastrointestinal digestion enhances the antioxidant activity of a bovine milk-based protein matrix (Power-Grant et al. 2016) as well as of a $\mathrm{K}$-casein and $\beta$-casein preparations (Petrat-Melin et al. 2015, 2016). Some antioxidant peptides (such as WSVPQPK and ISELGW) and free amino acids have been generated after in vitro gastrointestinal hydrolysis of human milk or infant formula (Raikos and Diassos 2014).

At present, in vitro digestion studies focused on single isolated proteins without considering the influence of other components present in dairy products such as fat. Therefore, our in vitro digestion study was targeted on the identification of antioxidant compounds released after the in vitro digestion from complex food matrices represented by whole, semi-skimmed and skimmed bovine milk.

\section{Materials and methods}

\subsection{Materials}

All electrophoresis, HPLC and MS/MS reagents were from BioRad (Hercules CA, USA), whereas the remaining chemicals were purchased from Sigma-Aldrich (Milan, Italy) unless otherwise stated. Amicon Ultra-4 regenerated cellulose $3 \mathrm{~kg} \cdot \mathrm{mol}^{-1}$ was supplied by Millipore (Billerica MA, USA). The homogenized bovine milk (whole, semi-skimmed and skimmed milk), belonging to the same batch of raw milk, was obtained from a local producer. The different types of milk had the same total proteins (3.1 $\left.\mathrm{g} \cdot 100 \mathrm{~mL}^{-1}\right)$, caseins $\left(2.6 \mathrm{~g} \cdot 100 \mathrm{~mL}^{-1}\right)$, carbohydrates $\left(4.8 \mathrm{~g} \cdot 100 \mathrm{~mL}{ }^{-1}\right)$ and calcium $\left(120 \mathrm{mg} \cdot 100 \mathrm{~mL}^{-1}\right)$ content but differ for the fat content $\left(3.60 \mathrm{~g} \cdot 100 \mathrm{~mL}^{-1}\right.$, $1.55 \mathrm{~g} \cdot 100 \mathrm{~mL}^{-1}$ and $0.05 \mathrm{~g} \cdot 100 \mathrm{~mL}^{-1}$ in whole, semi-skimmed and skimmed milk, respectively). The absorbance was read using a Jasco V-550 UV/Vis spectrophotometer (Orlando, FL, USA).

\subsection{In vitro gastrointestinal digestion}

The two-stage in vitro digestive model was adapted from Helal et al. (2014). Aliquots $(50 \mathrm{~mL})$ of milk were mixed with $50 \mathrm{~mL}$ of water. The samples were then brought to $\mathrm{pH} 2.5$ with concentrated $\mathrm{HCl}$ and the gastric digestion was started by the addition to the $100 \mathrm{~mL}$ of overall digestion media of $0.2 \mathrm{~g}$ of $\mathrm{NaCl}$ and $31,500 \mathrm{U}$ of pepsin. The samples were incubated at $37{ }^{\circ} \mathrm{C}$ in a shaking bath for $2 \mathrm{~h}$ to simulate the gastric phase of digestion. At the end of the gastric digestion, the $\mathrm{pH}$ was brought to 7.5 with $\mathrm{NaHCO}_{3}$, before adding 0.8 g. $\mathrm{L}^{-1}$ pancreatin and $5 \mathrm{mg} . \mathrm{mL}^{-1}$ bile salts. The solution was then incubated at $37{ }^{\circ} \mathrm{C}$ in a shaking bath for further $2 \mathrm{~h}$ to simulate the intestinal phase of digestion. The enzymes were inactivated by heating at $95{ }^{\circ} \mathrm{C}$ for $15 \mathrm{~min}$, followed by cooling to room temperature. Aliquots of the samples were withdrawn after mixing milk with

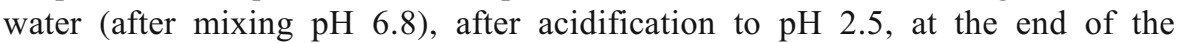
gastric digestion, after alkalinization to $\mathrm{pH} 7.5$ and at the end of the intestinal digestion. Each sample was digested in triplicate. 


\subsection{Determination of the degree of hydrolysis}

The determination of the degree of hydrolysis of the digested samples was carried out as reported by Adler-Nissen (1979). The hydrolysis degree was calculated as reported in Eq. 1:

$$
\mathrm{DH}=\left(h / h_{\mathrm{tot}}\right) \times 100
$$

where $h$ is the hydrolysis equivalent, defined as the concentration in milliequivalents per gramme of protein of $\alpha$-amino groups formed at the different stages of the simulated digestion, and $h_{\text {tot }}$ is the hydrolysis equivalent at complete hydrolysis to amino acids (calculated by summing the contents of the individual amino acids in $1 \mathrm{~g}$ of protein and considering caseins as the only proteins in milk). According to AdlerNissen (1979), the $h_{\text {tot }}$ value was fixed at 8 that is the value calculated for caseins.

\subsection{SDS-PAGE electrophoresis}

Samples of different types of un-fractionated milk taken at different times of digestion were subjected to sodium dodecyl sulfate polyacrylamide gel electrophoresis (SDSPAGE) using $17 \%$ polyacrylamide separating gel as reported in Helal et al. (2014). Three SDS gels were run of each milk sample.

\subsection{Fractionation of digested samples}

Samples from in vitro simulated digestion ( $4 \mathrm{~mL}$ of 5 times water-diluted sample) were subjected to ultrafiltration with Amicon Ultra-4 nominal cutoff $3 \mathrm{~kg} \cdot \mathrm{mol}^{-1}$ (Millipore, Italy), at $7500 \mathrm{~g}$ for $120 \mathrm{~min}$ at $4{ }^{\circ} \mathrm{C}$. At the end of the separation, two fractions were obtained: the retentate containing mainly high molecular weight compounds (HMW fraction; $>3 \mathrm{~kg} \cdot \mathrm{mol}^{-1}$ ) and the permeate containing low molecular weight compounds (LMW fraction; $<3 \mathrm{~kg} \cdot \mathrm{mol}^{-1}$ ). The two fractions were filled up to $4 \mathrm{~mL}$ with a solution of $\mathrm{HCl} 0.01 \mathrm{~mol} . \mathrm{L}^{-1}$ for the sample collected during the gastric phase of the digestion or potassium phosphate buffer $\left(0.1 \mathrm{~mol} . \mathrm{L}^{-1} ; \mathrm{pH} 7\right)$ for the sample collected during the intestinal phase.

\subsection{Reversed-phase high-performance liquid chromatography analysis of peptides}

High-performance liquid chromatography (HPLC) separation of the low molecular weight fractions of digested milk collected at the end of the pancreatic digestion was performed with a Jasco HPLC system equipped with a reversed-phase column Hamilton HxSil C18 (Hamilton, Reno, Nevada; $250 \mathrm{~mm} \times 4.6 \mathrm{~mm}, 5 \mu \mathrm{m}, 100 \AA$ ) as described in Tagliazucchi et al. (2015). The two solvents were solvent A mixture of water-trifluoroacetic acid (0.037\%) and solvent B acetonitriletrifluoroacetic acid $(0.027 \%)$. A linear gradient of solvent B in A ranging from 0 to $45 \%$ in $115 \mathrm{~min}$ with a flow rate of $0.5 \mathrm{~mL} \cdot \mathrm{min}^{-1}$ was used to separate the peptides contained in the low molecular fractions of digested milk. The photodiode array (PDA) detector was set at $214 \mathrm{~nm}$. Twelve fractions from digested skimmed milk were collected and freeze-dried. These fractions were re- 
filled to the original volume with a potassium phosphate buffer $\left(0.1\right.$ mol.L ${ }^{-1}$; $\mathrm{pH}$ 7) and then analysed for their antioxidant activity.

\section{7 $\mathrm{ABTS}^{+}$radical scavenging activity of digested samples and antioxidant properties of selected HPLC fractions and amino acids}

The antioxidant activity of the sample collected during the in vitro digestion procedure and from HPLC separation was determined using 2,2'-azino-bis(3-ethylbenzothiazoline-6-sulphonic acid (ABTS) method as described in Re et al. (1999) both on unfractionated and fractionated samples. The $\mathrm{ABTS}^{+}$scavenging capacity was expressed as milligram of vitamin $\mathrm{C}$ per litre of milk, by means of a calibration curve obtained with vitamin $\mathrm{C}$ (ranging from 1 to $150 \mathrm{mg} . \mathrm{L}^{-1}$ ), in the same assay conditions.

The antioxidant properties of the selected HPLC fractions and amino acids were evaluated using three different assays.

The ABTS assay was carried out as described above.

The capacity to scavenge hydroxyl radicals was evaluated according to a method reported by Ajibola et al. (2011) with some modifications. The assay consisted of mixing $50 \mu \mathrm{L}$ of $3 \mathrm{mmol} . \mathrm{L}^{-1} \mathrm{TPTZ}$ (2,4,6-tri(2-pyridyl)-s-triazine) dissolved in $\mathrm{HCl}$ $50 \mathrm{mmol} . \mathrm{L}^{-1}, 50 \mu \mathrm{L}$ of $3 \mathrm{mmol} . \mathrm{L}^{-1} \mathrm{FeSO}_{4}, 50 \mu \mathrm{L}$ of sample or vitamin $\mathrm{C}$ (at concentration ranging from 1 to $\left.10 \mathrm{mmol} . \mathrm{L}^{-1}\right)$, and $50 \mu \mathrm{L}$ of $0.01 \%(v / v)$ hydrogen peroxide, in a clear bottom 96-well plate. The mixture was incubated for $1 \mathrm{~h}$ at $37{ }^{\circ} \mathrm{C}$, and the absorbance was measured at $540 \mathrm{~nm}$ using a microplate reader.

The ABTS and hydroxyl radical scavenging capacities were expressed as milligram of vitamin $\mathrm{C}$ per litre of milk or, in the case of the amino acids, as milligram vitamin $\mathrm{C}$ per millimole of amino acid.

The ability to inhibit lipid peroxidation was carried out using a linoleic acid emulsion system (Ajibola et al. 2011). For that purpose, $200 \mu \mathrm{L}$ of the sample at concentration of $2 \mathrm{mmol} . \mathrm{L}^{-1}, 200 \mu \mathrm{L}$ of $99.5 \%$ ethanol and $2.6 \mu \mathrm{L}$ of linoleic acid were mixed and the total volume was adjusted to $500 \mu \mathrm{L}$ with sodium phosphate buffer, 50 mmol.L $\mathrm{L}^{-1}$, and $\mathrm{pH}$ 7.0. The mixture was incubated at $40{ }^{\circ} \mathrm{C}$ in the dark for 7 days. The amount of generated lipid hydroperoxide was measured by the FOX assay as reported by Tagliazucchi et al. (2010). The lipid peroxidation inhibitory activity of the samples was expressed as percentage of inhibition with respect to a control reaction without the sample.

\subsection{Peptide profile determination with nanoflow liquid chromatography accurate mass quadrupole time-of-flight mass spectrometry with electrospray ionization (LC-ESI-QTOF MS)}

The fractions with the highest antioxidant activity were subjected to QTOF MS/MS analysis for peptide identification. Nano-LC/MS and tandem MS experiments were performed on a 1200 series liquid chromatographic two-dimensional system coupled to a 6520 accurate-mass QTOF LC/MS via a Chip Cube Interface (Agilent Technologies). Chromatographic separation was performed on a ProtID-Chip-43(II) including a 4-mm, 40-nL enrichment column and a $43 \mathrm{~mm} \times 75 \mu \mathrm{m}$ analytical column, both packed with a Zorbax 300SB $5 \mu \mathrm{m} \mathrm{C18}$ phase (Agilent Technologies). The mobile phases composition and the gradient were the same as reported by Tagliazucchi et al. (2015). The mass 
spectrometer was tuned, calibrated and set with the same parameters as reported by Dei Più et al. (2014).

For peptide identification and sequencing, MS/MS spectra were converted to .mgf, and de novo peptide sequencing was performed using Pepnovo software (http:// proteomics.ucsd.edu/ProteoSAFe/). The following parameters were considered: enzyme, none; peptide mass tolerance, $\pm 40 \mathrm{ppm}$; fragment mass tolerance, \pm 0 . $12 \mathrm{Da}$; variable modification, oxidation (M) and phosphorylation (ST); maximal number of PTMs permitted in a single peptide 3.

A search for the biological activity of peptides identified was carried out through the BIOPEP database (http://www.uwm.edu.pl/biochemia/biopep/start_biopep.php). Confirmation of peptides sequence in bovine milk proteins was performed using Peptide Match http://research.bioinformatics.udel.edu/peptidematch/index.jsp).

\subsection{HPLC analysis of tyrosine and tryptophan}

The amount of tyrosine in F2 and tryptophan in F5 was determined according to Frank and Powers (2007). Derivatization was carried out by mixing $50 \mu \mathrm{L}$ of sample with $50 \mu \mathrm{L}$ of OPA (ortho-phthalaldehyde) solution (consisting of $7.45 \mathrm{mmol} . \mathrm{L}^{-1}$ of OPA and 11.4 mmol. $\mathrm{L}^{-1}$ of 3 -mercaptopropionic acid in potassium tetraborate buffer $0.2 \mathrm{mmol}^{-1} \mathrm{pH}$ 9.5). The HPLC separation of the derivatized amino acids was carried out with the same C18 column as reported in section " 2.6 " using a binary gradient of mobile phase A $\left(30 \mathrm{mmol} . \mathrm{L}^{-1}\right.$ potassium phosphate buffer with $0.4 \%$ tetrahydrofuran $\mathrm{pH} 7.0)$ and mobile phase $\mathrm{B}(50 \%$ acetonitrile and $50 \%$ water). The gradient started at $0 \% \mathrm{~B}$ for $0.5 \mathrm{~min}$ then linearly ramped up to $48 \% \mathrm{~B}$ in $22 \mathrm{~min}$. The mobile phase composition was raised up to $60 \% \mathrm{~B}$ in $12 \mathrm{~min}$, then $100 \% \mathrm{~B}$ in $1 \mathrm{~min}$ and maintained for $4 \mathrm{~min}$ in order to wash the column. Flow rate was $1 \mathrm{~mL} \cdot \mathrm{min}^{-1}$. The detection was performed at $340 \mathrm{~nm}$.

\subsection{Statistical analysis}

All data are presented as mean \pm SD for three independent in vitro digestion experiments performed on the same milk sample. Two-way univariate analysis of variance (ANOVA) with Tukey's post hoc test was applied to determine significant differences $(P<0.05)$. Correlations between variables were assessed using Pearson's method. All analyses were performed with GraphPad Prism version 6.00 (GraphPad software, San Diego, CA, USA).

\section{Results and discussion}

\subsection{Assessment of protein hydrolysis during simulated digestion of whole, semi-skimmed and skimmed milk}

Simulated gastrointestinal digestion of whole, semi-skimmed and skimmed milk resulted in the partial hydrolysis of the milk proteins with formation of peptides with a molecular weight lower than $10 \mathrm{~kg} \cdot \mathrm{mol}^{-1}$ as showed by electrophoresis (data not shown). As detailed in Table 1, the degree of hydrolysis (DH) of the different types 
Table 1 Degree of hydrolysis (DH) of bovine milk proteins before and after in vitro gastrointestinal digestion. Data are means $\pm \mathrm{SD} ; n=3$

\begin{tabular}{lccc}
\hline Sample & Whole milk & Semi-skimmed milk & Skimmed milk \\
\hline Before digestion & $3.1 \pm 0.5^{\mathrm{a}}$ & $2.8 \pm 0.5^{\mathrm{a}}$ & $3.1 \pm 0.2^{\mathrm{a}}$ \\
After peptic digestion & $7.2 \pm 0.6^{\mathrm{b}}$ & $7.4 \pm 0.2^{\mathrm{b}}$ & $8.8 \pm 0.7^{\mathrm{c}}$ \\
After pancreatic digestion & $20.8 \pm 0.4^{\mathrm{d}}$ & $24.3 \pm 0.3^{\mathrm{e}}$ & $30.7 \pm 0.8^{\mathrm{f}}$ \\
\hline
\end{tabular}

${ }^{\mathrm{a}-\mathrm{f}}$ Significant differences are shown by different letters (Tukey's test, $P<0.05$ )

of milk at time $0 \mathrm{~h}$ was similar and not statistically different (average $\mathrm{DH}$ value $2.9 \pm 0.3)$ regardless of milk type. DH increased significantly $(P<0.05)$ during the peptic digestion for all the samples but with some differences. The DH after peptic digestion was higher for samples with low fat content (skimmed $>$ semiskimmed $>$ whole milk). The pancreatic digestion produced a high and significant $(P<0.05)$ increase in $\mathrm{DH}$ for all the digested samples. The degree of protein hydrolysis was different considering the various types of milk and in particular was higher for milk poor in fat with respect to the milk rich in fat, despite having the same protein content. Results showed that the presence of fat reduces the proteolysis both at gastric and intestinal level. The exact mechanism is not known and currently under investigation. It could be expected that since surface plays a very important part in enzyme action, fats may reduce surface tension and so lower surface energy, hence retard protein digestion.

The DH value measured after gastrointestinal digestion with our model was lower than that determined by Picariello et al. (2015) which found a degree of hydrolysis for skimmed milk between 34.5 and 58 depending on the substrate to digestive enzyme ratio. Simulated digestion of isolated $\kappa$ - and $\beta$-casein resulted in a hydrolysis degree between 40 and 55 (Petrat-Melin et al. 2015; Petrat-Melin et al. 2016).

\section{2 $\mathrm{ABTS}^{+}$radical scavenging activity of digested whole, semi-skimmed and skimmed milk}

All three types of milk showed $\mathrm{ABTS}^{+}$radical scavenging activity before the digestion (Table 2), but with some differences. Skimmed milk had a significant minor radical scavenging activity with respect to whole milk $(P<0.05)$. The higher value of $\mathrm{ABTS}^{+}$ radical scavenging activity in samples with more fats can be due to the reactivity of lipid soluble antioxidants, such as $\alpha$-tocopherol and carotenoids (Re et al. 1999) and fat globule membrane proteins with $\mathrm{ABTS}^{+}$radical. More than $90 \%$ of the antioxidant activity in all the analysed types of milk was in the $>3 \mathrm{~kg}^{\mathrm{mol}}{ }^{-1} \mathrm{HMW}$ fraction underlining the role of protein in the total radical scavenging activity of milk. Clausen et al. (2009) found that caseins are quantitatively the highest radical scavengers in milk whereas the lower contribution of the LMW fraction is due to ascorbate and especially urate. Caseins have a high content of antioxidative amino acids such as tyrosine, tryptophan and phosphoserine, and quenching of free radicals by oxidation of these amino acids was proposed as the explanation (Clausen et al. 2009; Cervato et al. 1999).

After acidification of the milk samples to $\mathrm{pH} 2.5$ (corresponding to the time zero of the gastric digestion), the $\mathrm{ABTS}^{+}$radical scavenging activity decreased significantly in 


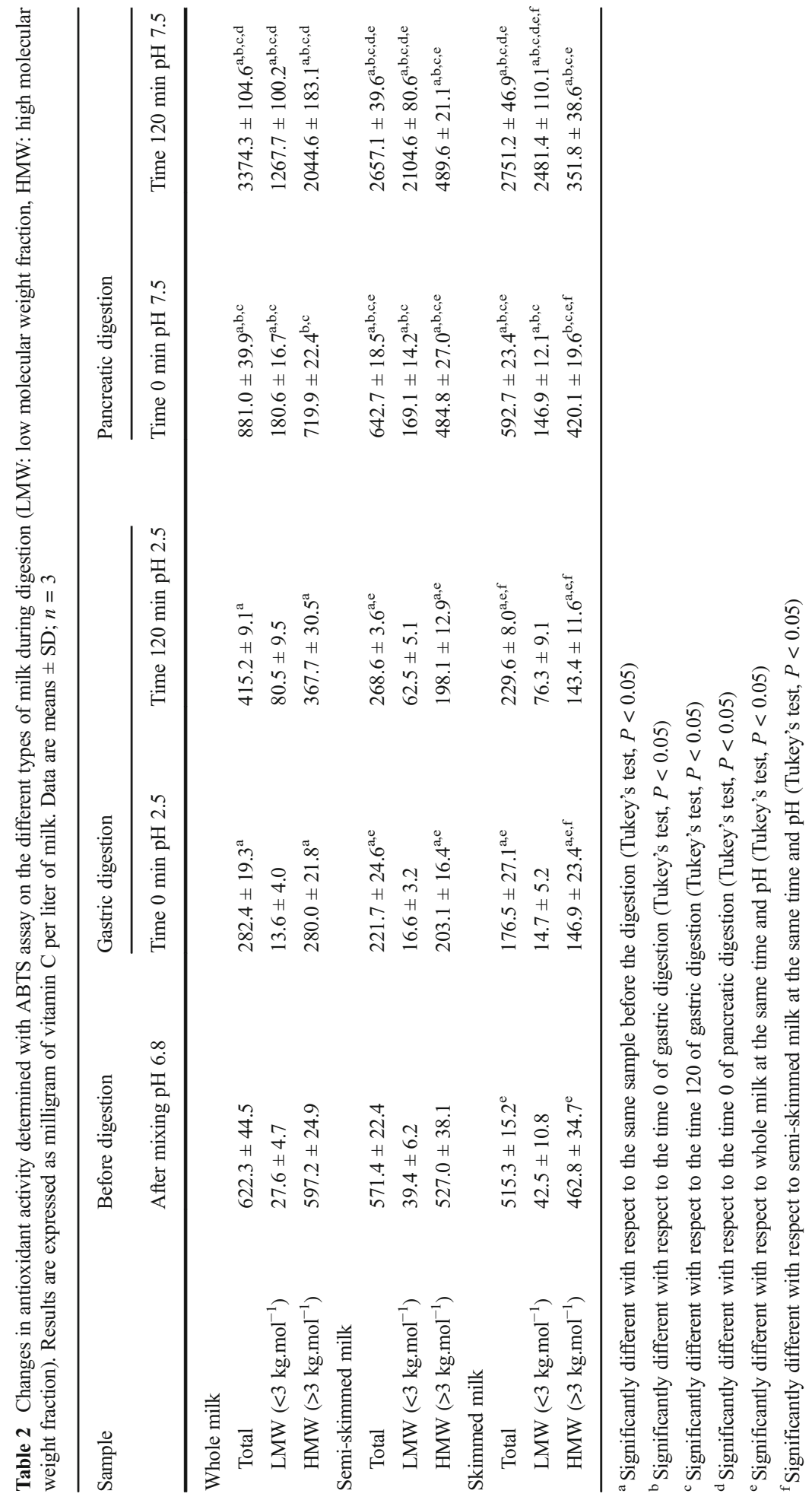


all three types of milk. This decrease was caused by a drop in the $\mathrm{ABTS}^{+}$value of the HMW fraction whereas the value in the LMW fraction was unaffected. The gastric $\mathrm{pH}$ value $(\mathrm{pH} 2.5)$ is near to the isoelectric point of casein $(\mathrm{p} I$ 4.6) and this determines changes in casein aggregation with a masking of antioxidant sequences of amino acids, which can explain the decrease in $\mathrm{ABTS}^{+}$radical scavenging activity after acidification. After 120 min of peptic digestion, the total $\mathrm{ABTS}^{+}$value increased non-significantly with respect to the time zero of gastric digestion in all the milk types. However, the $\mathrm{ABTS}^{+}$radical scavenging activity was always lower than the original value found in the different types of milk before the digestion except in the LMW fractions. The main contribution to $\mathrm{ABTS}^{+}$value, for all the types of milk beverages after peptic digestion, was due to HMW fraction. The HMW fraction $\mathrm{ABTS}^{+}$radical scavenging activity decreased from the milk richest to the milk poorest in fats.

The passage into the alkaline media, from $120 \mathrm{~min}$ of the gastric digestion ( $\mathrm{pH}$ 2.5) to time $0 \mathrm{~min}$ of the pancreatic digestion $(\mathrm{pH} 7.5)$, led to an increase in the $\mathrm{ABTS}^{+}$ radical scavenging activity in total and LMW and HMW fractions of all the types of milk beverages.

After 120 min of pancreatic digestion, there was a high increase in the $\mathrm{ABTS}^{+}$value for all the three types of milk beverages. Whole milk showed the highest increase whereas there were no statistically differences between semi-skimmed and skimmed milk.

The distribution of the radical scavenging activity between the LMW and HMW fractions was different considering the diverse types of milk. In digested whole milk, the main contribution to $\mathrm{ABTS}^{+}$radical scavenging activity was due to HMW fraction. For semi-skimmed and skimmed milk, the main contribution was due to LMW fraction. During in vitro gastrointestinal digestion of bovine milk, protein hydrolysis determines the formation of low molecular weight peptides with $\mathrm{ABTS}^{+}$radical scavenging activity probably due to unmasking and liberation of some amino acid sequences with antioxidant activities that are buried or inactive in the intact proteins. Hydrolysates obtained after peptic, tryptic and chymotryptic hydrolysis of milk proteins showed radical scavenging activity (Pihlanto 2006; Hernández-Ledesma et al. 2005). There is a clear correlation (Pearson coefficient $r=0.928 ; P<0.05$ ) between the DH and the amount of $\mathrm{ABTS}^{+}$radical scavenging activity found in LMW fractions. The whole milk sample showed the lowest DH after pancreatic digestion, and only $38 \%$ of $\mathrm{ABTS}^{+}$radical scavenging activity was found in the LMW fraction. The percentage of $\mathrm{ABTS}^{+}$radical scavenging activity in the LMW fraction increased to 79 and $90 \%$ in semi-skimmed and skimmed milk samples, respectively, according to the increase in the hydrolysis degree. The fat content negatively influenced the $\mathrm{LMW} \mathrm{ABTS}^{+}$radical scavenging activity at the end of the digestion. Indeed, the presence of fat may lead to peroxidative phenomena during gastrointestinal digestion causing depletion of antioxidant compounds. This fact may result in a lower $\mathrm{ABTS}^{+}$reactivity in the samples richest in fat.

\subsection{Antioxidant properties of the HPLC fractions from the permeate of digested skimmed milk}

The peptides in the LMW fractions of digested milk were separated in the HPLC C18 column and detected at $214 \mathrm{~nm}$ with PDA. As reported in Fig. 1, the LMW fractions of 

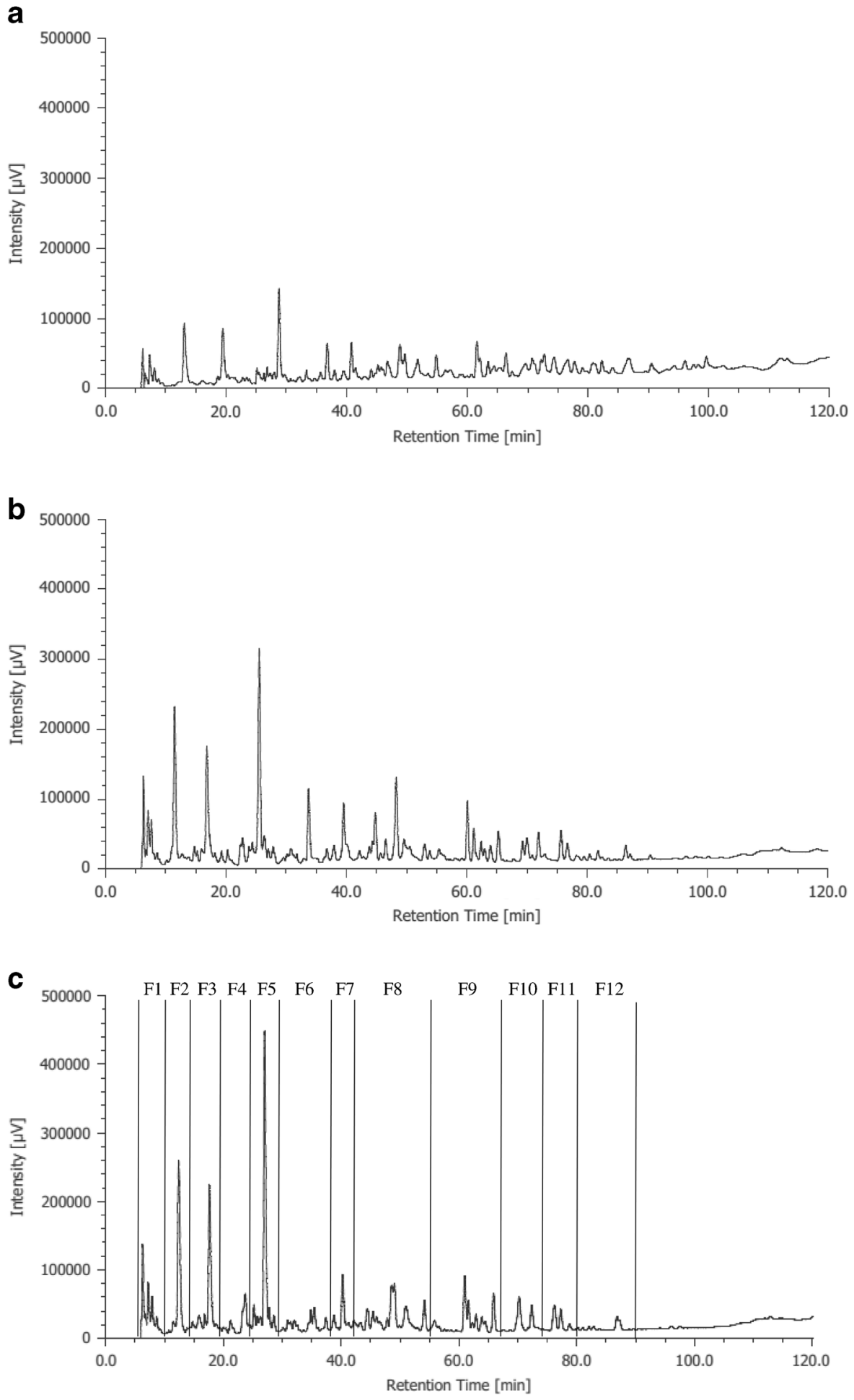
Fig. 1 UV-chromatograms of the low molecular weight fractions $\left(<3 \mathrm{~kg} \cdot \mathrm{mol}^{-1}\right)$ obtained from the whole (a), semi-skimmed (b) and skimmed (c) bovine milk after in vitro gastrointestinal digestion. Twelve fractions (from F1 to F12) were collected from the low molecular weight fraction of skimmed milk (see panel c). Detection was achieved at $214 \mathrm{~nm}$. The showed chromatograms are representative of three independent experiments

the three different types of milk showed the same HPLC pattern with only difference in the intensity of the peaks.

Due to its high $\mathrm{ABTS}^{+}$radical scavenging activity, the LMW fraction of skimmed milk was selected for MS/MS experiments with the aim to identify the compounds responsible for the activity.

Twelve fractions from skimmed milk permeate (Fig. 1c) were collected, freeze-dried and evaluated for their $\mathrm{ABTS}^{+}$radical scavenging activity. Only seven fractions were found to have a considerable $\mathrm{ABTS}^{+}$radical scavenging activity (Fig. 2).

Three fractions (F2, F3 and F5) were found to be the major contributors on the $\mathrm{ABTS}^{+}$radical scavenging activity of the skimmed milk LMW fraction. These three fractions were further characterized for their ability to scavenge hydroxyl radical and to inhibit lipid peroxidation. All of the three fractions exhibited a certain degree of hydroxyl scavenging activity. Fraction F2 was the most active against hydroxyl radical whereas fraction F3 showed the highest lipid peroxidation inhibitory activity (Table 3).

The compounds responsible for the antioxidant activity of these three fractions were tentatively identified with mass spectrometry.

\subsection{Nano-LC-ESI-QTOF-MS/MS analysis of the HPLC collected fractions}

Figure 3 shows the full MS spectra of the fractions F2, F3 and F5. Each peak was selected for peptide identification by MS/MS ion scan using de novo sequencing software. Results from the peptide identification were subjected to a manual evaluation, and the validated peptide sequences explained most of the major peaks in the MS spectra.

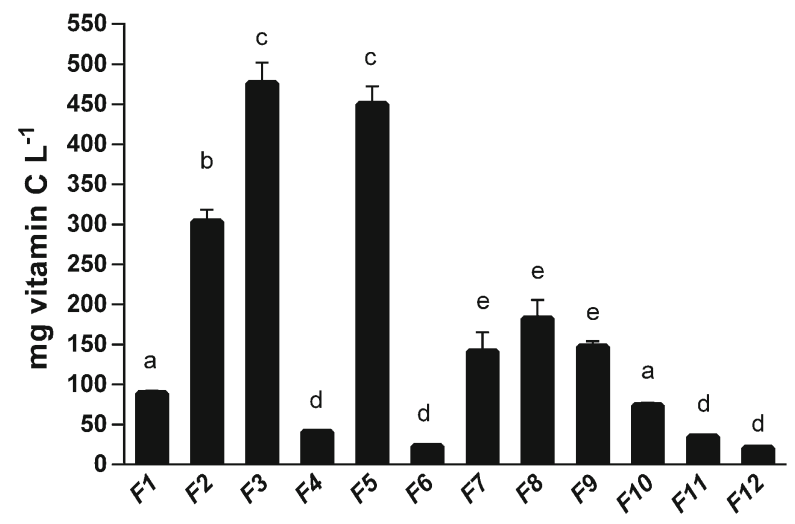

Fig. 2 Antioxidant activity of the high-performance liquid chromatography-collected fractions from permeate $\left(<3 \mathrm{~kg} \cdot \mathrm{mol}^{-1}\right)$ obtained from skimmed bovine milk after in vitro gastrointestinal digestion. Bars with different letters are different from one another $(P<0.05)$ based on two-way ANOVA analysis of variance and subsequent Tukey's post hoc test 
Table 3 Radical scavenging properties and lipid peroxidation inhibitory activity of the reversed-phase highperformance liquid chromatography fractions F2, F3 and F5 of $<3 \mathrm{~kg} \cdot \mathrm{mol}^{-1}$ permeate obtained from skimmed bovine milk after in vitro gastrointestinal digestion

\begin{tabular}{llll}
\hline & $\begin{array}{l}\text { ABTS radical } \\
\text { scavenging } \\
\text { mg vitamin } \mathrm{C} \cdot \mathrm{L}^{-1}\end{array}$ & $\begin{array}{l}\text { Hydroxyl radical } \\
\text { scavenging } \\
\text { mg vitamin } \mathrm{C} \cdot \mathrm{L}^{-1}\end{array}$ & $\begin{array}{l}\text { Inhibition of lipid } \\
\text { peroxidation } \\
\% \text { of inhibition }\end{array}$ \\
\hline F2 & $303.1 \pm 12.8^{\mathrm{a}}$ & $4643.1 \pm 153.6^{\mathrm{a}}$ & $21.0 \pm 3.6^{\mathrm{a}}$ \\
F3 & $476.0 \pm 27.7^{\mathrm{b}}$ & $1084.4 \pm 61.9^{\mathrm{b}}$ & $97.4 \pm 4.7^{\mathrm{b}}$ \\
F5 & $450.0 \pm 25.3^{\mathrm{b}}$ & $457.8 \pm 28.1^{\mathrm{c}}$ & $58.9 \pm 7.3^{\mathrm{c}}$ \\
\hline
\end{tabular}

Data are means $\pm \mathrm{SD}(n=3)$. Values in the same columns with different lowercase letters are significantly different (Tukey's test; $P<0.05$ )

In the lowest part of the MS spectra of fraction F2 (Fig. 3a), the most intense signals were identified as the amino acids (iso)leucine $(\mathrm{Lx} ; m / z=132.1037)$ and tyrosine $(\mathrm{Y} ; \mathrm{m} / \mathrm{z}=182.0851)$, and the dipeptide GP $(\mathrm{m} / \mathrm{z}=173.0840)$. Additional intense signals were identified as the dipeptide GLx $(m / z=189.1246)$ and the tripeptides $\operatorname{VVD}(\mathrm{m} / \mathrm{z}=332.1821)$ and LSH $(\mathrm{m} / \mathrm{z}=356.1945)$. The list of compounds identified in fraction F2 is shown in Table 4 together with the MS data, the protein precursor and the potential bioactivity.

In the lowest part of the MS spectra of fraction F3 (Fig. 3b), the most intense signals were identified as the amino acid phenylalanine $(\mathrm{F} ; \mathrm{m} / \mathrm{z}=166.1055)$ and the dipeptide GP $(m / z=173.0819)$. An additional signal at $m / z$ of 120.0859 was assigned to the amino acid threonine. In the peptidic part of the spectra, the most intense signals corresponded to the dipeptides VLx $(m / z=231.1736), \operatorname{ALx}(m / z=203.1415)$ and QLx $(m / z=260.1639)$ and the tripeptide SLxT $(m / z=320.1849)$. The list of compounds identified in fraction F3 is shown in Table 4 together with the MS data, the protein precursor and the potential bioactivity.

An additional free aromatic amino acid, tryptophan $(\mathrm{W} ; m / z=205.2208)$, gave an intense signal in the fraction F5 (Fig. 3c). The most intense signals in the peptidic part of the MS spectra of fraction F5 were identified as the tetrapeptide SAPL $(m / z=387.2272)$ from $\beta$-lactoglobulin (f36-39) and the $\alpha_{\mathrm{S} 1 \text {-casein-derived }}$ (f8-13) peptide HQGLPQ $(\mathrm{m} / \mathrm{z}=340.1831$; double-charged ion). Additional high signals were attributed to the peptide TKIPA from $\beta$-lactoglobulin (f76-80) present both as double-charged $(\mathrm{m} / \mathrm{z}=265.1741)$ and mono-charged $(\mathrm{m} / \mathrm{z}=529.3435)$ ions and the $\alpha_{\mathrm{S} 2}$-casein-derived peptides ITVDDK (f71-76) as double-charged ion $(m / z=345.6897)$ and FPQ (f92-94) with $m / z$ value of 391.2055. The peptide AMEDIK $\left(\alpha_{\mathrm{S} 1}\right.$-casein f53-58) was present in the spectra both in reduced and oxidized (at methionine level) forms with $\mathrm{m} / \mathrm{z}$ values of 353.6766 and 361.6770 , respectively (Table 5).

\subsection{Identification of antioxidant compounds in HPLC fractions F2, F3 and F5}

To identify the amino acids and peptides with the most potential antioxidant activity, the antioxidant properties of the peptides constitutive amino acids were determined (Table 6). Tryptophan was the amino acid with the highest $\mathrm{ABTS}^{+}$value followed by 
a

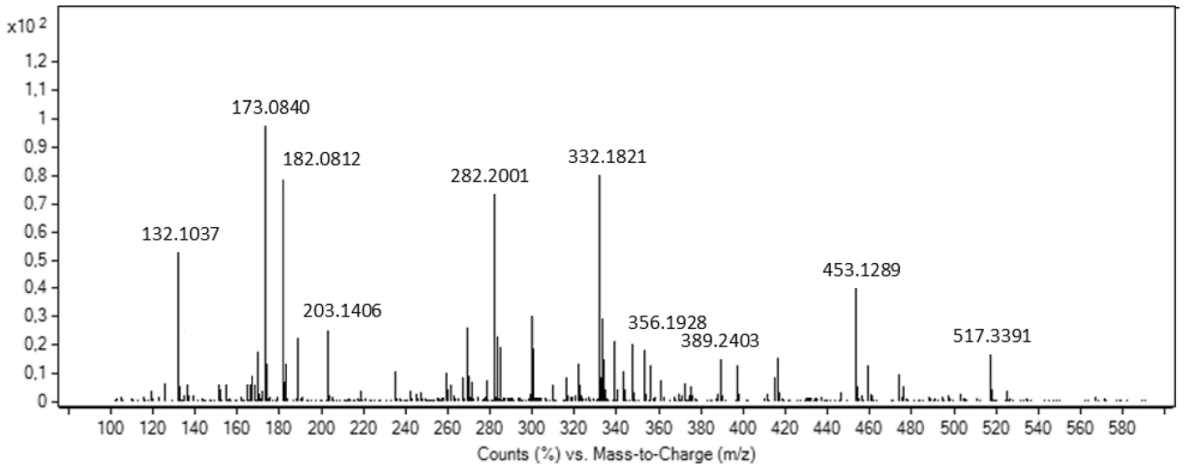

b

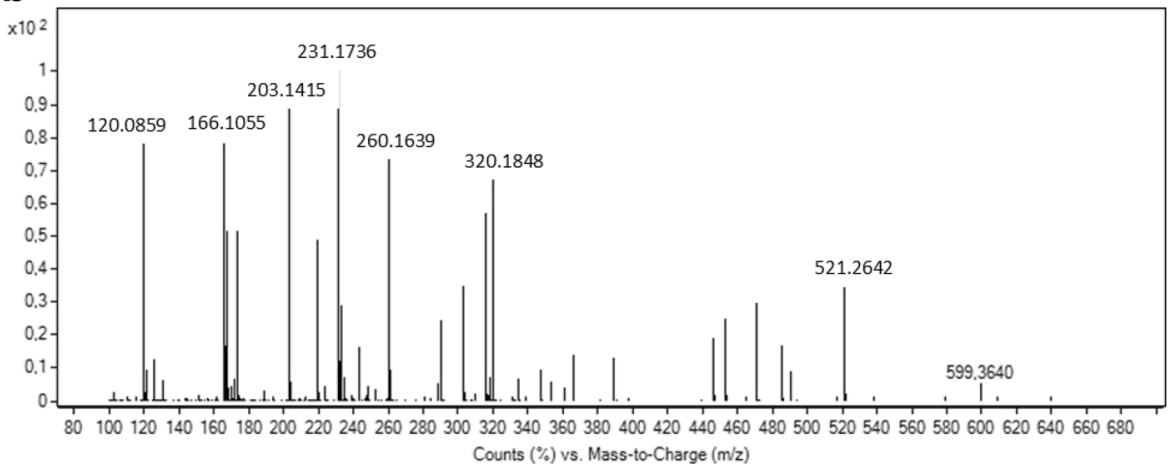

C

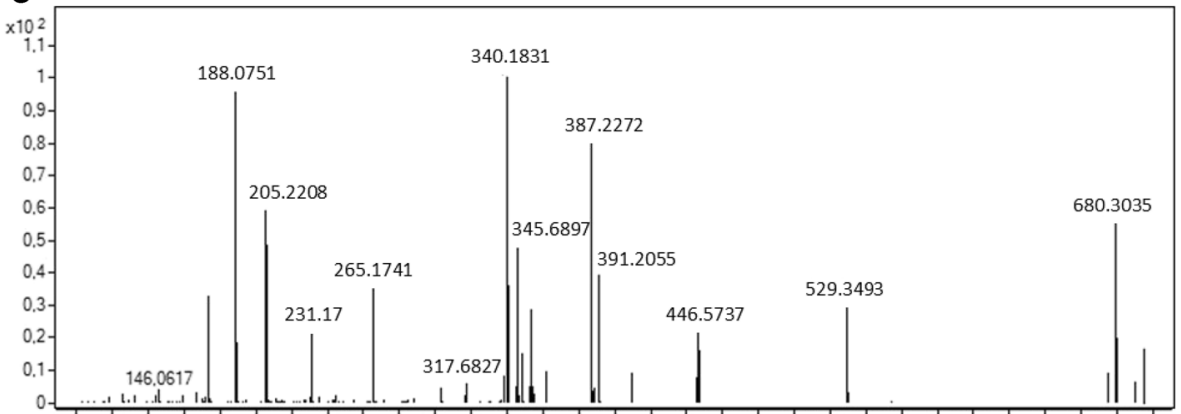

100120140160180200220240260280300320340360380400420440460480500520540560580600620640660680700 Counts $(\%)$ vs. Mass-to-Charge $(\mathrm{m} / \mathrm{z})$

Fig 3 Mass spectrum of high-performance liquid chromatography fraction F2 (a), F3 (b) and F5 (c) from nano-LC-QTOF MS/MS analysis of the permeate $\left(<3 \mathrm{~kg} \cdot \mathrm{mol}^{-1}\right)$ obtained from skimmed bovine milk after in vitro gastrointestinal digestion. Identified compounds are reported in Tables 4 and 5. The showed mass spectra are representative of three independent experiments

cysteine and tyrosine. The rest of the amino acids analysed did not exhibit antioxidant activity with this method at $2 \mathrm{mmol} . \mathrm{L}^{-1}$ concentration. Tyrosine and cysteine were also the amino acids with the highest hydroxyl radical scavenging activity followed by methionine and tryptophan. The amino acids phenylalanine and histidine showed the highest ability to inhibit lipid peroxidation. The amino acid tryptophan appeared to be the most effective as antioxidant since it showed high activity in all the assays. 
Table 4 Compounds identified in the reversed-phase high-performance liquid chromatography fractions F2 and $\mathrm{F} 3$ of $<3 \mathrm{~kg} \cdot \mathrm{mol}^{-1}$ permeate obtained from skimmed bovine milk after in vitro gastrointestinal digestion

\begin{tabular}{|c|c|c|c|c|c|}
\hline Fraction & $\begin{array}{l}\text { Observed } \\
\operatorname{mass}(\mathrm{m} / \mathrm{z})\end{array}$ & $\begin{array}{l}\text { Calculated } \\
\text { mass }^{\mathrm{a}}\end{array}$ & $\begin{array}{l}\text { Peptide } \\
\text { sequence }^{b}\end{array}$ & Protein precursor & Bioactivity $^{\mathrm{c}}$ \\
\hline \multirow[t]{6}{*}{$\mathrm{F} 2$} & 132.1037 & 132.1025 & $\mathrm{Lx}$ & Various proteins & / \\
\hline & 182.0851 & 182.0812 & $\mathrm{Y}$ & Various proteins & Antioxidant \\
\hline & 173.0840 & 173.0921 & GP & Various proteins & $\begin{array}{l}\text { Peptide regulating the stomach } \\
\text { mucosal membrane } \\
\text { activity; } \\
\text { DPP IV inhibitor; } \\
\text { ACE inhibitor; } \\
\text { PEP inhibitor }\end{array}$ \\
\hline & 189.1246 & 189.1234 & GLx & Various proteins & $\begin{array}{l}\text { DPP IV inhibitor (GI); } \\
\text { ACE inhibitor (GL/GI) }\end{array}$ \\
\hline & 332.1821 & 332.1816 & VVD & $\begin{array}{l}\text { Digestive enzymes } \\
\quad(\alpha \text {-amylase, lipase })\end{array}$ & / \\
\hline & 356.1945 & 356.1928 & LSH & Various proteins & / \\
\hline \multirow[t]{13}{*}{ F3 } & 120.0859 & 120.0655 & $\mathrm{~T}$ & Various proteins & / \\
\hline & 166.1055 & 166.0863 & $\mathrm{~F}$ & Various proteins & / \\
\hline & 173.0819 & 173.0921 & GP & Various proteins & $\begin{array}{l}\text { Peptide regulating the stomach } \\
\text { mucosal membrane activity; } \\
\text { DPP IV inhibitor; } \\
\text { ACE inhibitor; } \\
\text { PEP inhibitor }\end{array}$ \\
\hline & 203.1415 & 203.1309 & ALx & Various proteins & $\begin{array}{l}\text { DPP IV inhibitor (AL); } \\
\text { ACE inhibitor (AI) }\end{array}$ \\
\hline & 219.1533 & 219.1339 & SLx & Various proteins & DPP IV inhibitor (SL/SI) \\
\hline & 231.1736 & 231.1703 & VLx & Various proteins & $\begin{array}{l}\text { Glucose uptake stimulating } \\
\text { peptide (VL); } \\
\text { DPP IV inhibitor (VL/VI) }\end{array}$ \\
\hline & 260.1639 & 260.1605 & QLx & Various proteins & DPP IV inhibitor (QL/QI) \\
\hline & 275.6693 & 550.3348 & VRYL & $\alpha_{\mathrm{S} 2}$-casein $\mathrm{f}(205-208)$ & $\begin{array}{l}\text { ACE inhibitor; } \\
\text { Fragment and precursor of } \\
\text { antioxidant peptide }\end{array}$ \\
\hline & 320.1849 & 320.1816 & SLxT & $\beta$-casein (various fragments) & / \\
\hline & 334.1987 & 334.1973 & TLT & $\beta$-casein $\mathrm{f}(126-128)$ & / \\
\hline & 485.3159 & 485.3082 & IQPK & $\alpha_{\mathrm{S} 2 \text {-casein f (194-197) }}$ & / \\
\hline & 521.2642 & 521.2606 & YPEL & $\alpha_{\mathrm{S} 1}$-casein f (146-149) & Antioxidant \\
\hline & 674.3555 & 674.3508 & AVPYPQ & $\beta$-casein $f(177-182)$ & $\begin{array}{l}\text { Precursor of antioxidant } \\
\text { peptide }\end{array}$ \\
\hline
\end{tabular}

$A C E$ angiotensin converting enzyme, DPP IV dipeptidyl peptidase IV, PEP prolyl endopeptidase

${ }^{\text {a }}$ Monoisotopic mass

${ }^{\mathrm{b}} L x$ indicates leucine or isoleucine

${ }^{\mathrm{c}}$ Potential bioactivities were achieved from the BIOPEP database

Therefore, only the peptides containing the amino acids with antioxidant properties as well as the corresponding free amino acids were considered as potential radical scavengers.

Among the different compounds identified in fraction F2, tyrosine seemed fundamental in the $\mathrm{ABTS}^{+}$and hydroxyl radical scavenging capacities of the fraction and to play a role in the inhibition of formation of lipid hydroperoxide. Tyrosine was further quantified in the fraction resulting in a concentration of $2.2 \pm 0.1 \mathrm{mmol} . \mathrm{L}^{-1}$ of milk. 
Table 5 Compounds identified in the reversed-phase high-performance liquid chromatography fraction F5 of $<3 \mathrm{~kg} \cdot \mathrm{mol}^{-1}$ permeate obtained from skimmed bovine milk after in vitro gastrointestinal digestion

\begin{tabular}{|c|c|c|c|c|c|}
\hline Fraction & $\begin{array}{l}\text { Observed } \\
\operatorname{mass}(m / z)\end{array}$ & $\begin{array}{l}\text { Calculated } \\
\text { mass }^{\mathrm{a}}\end{array}$ & $\begin{array}{l}\text { Peptide } \\
\text { sequence }^{\text {b }}\end{array}$ & Protein precursor & Bioactivity $^{\mathrm{c}}$ \\
\hline \multirow[t]{14}{*}{ F5 } & 205.2208 & 205.2262 & W & Various proteins & Antioxidant \\
\hline & 231.1734 & 231.1703 & $\mathrm{LxV}$ & Various proteins & $\begin{array}{l}\text { Glucose uptake } \\
\text { stimulating } \\
\text { peptide (LV/IV); } \\
\text { DPP IV inhibitor (LV) }\end{array}$ \\
\hline & 231.1734 & 231.1703 & VLx & Various proteins & $\begin{array}{l}\text { Glucose uptake } \\
\text { stimulating } \\
\text { peptide (VL); } \\
\text { DPP IV inhibitor (VL/VI) }\end{array}$ \\
\hline & 265.1741 & 529.3344 & TKIPA & $\beta$-lactoglobulin $\mathrm{f}(76-80)$ & l \\
\hline & 295.1655 & 295.1652 & YLxx & Various proteins & $\begin{array}{l}\text { DPP IV inhibitor (YL/YI); } \\
\text { ACE inhibitor (YL) } \\
\text { Fragment of antioxidant } \\
\text { peptides }\end{array}$ \\
\hline & 317.6827 & 634.3923 & YKVPK & $\alpha_{\mathrm{S} 1}$-casein $\mathrm{f}(104-108)$ & l \\
\hline & 340.1831 & 679.3522 & HQGLPQ & $\alpha_{\mathrm{S} 1}$-casein $\mathrm{f}(8-13)$ & l \\
\hline & 345.6897 & 690.3668 & ITVDDK & $\alpha_{\mathrm{S} 2}$-casein $\mathrm{f}(71-76)$ & l \\
\hline & 353.6766 & 706.3440 & AMEDIK & $\alpha_{\mathrm{S} 1}$-casein $\mathrm{f}(53-58)$ & l \\
\hline & 387.2272 & 387.2165 & SAPL & $\beta$-lactoglobulin f (36-39) & / \\
\hline & 391.2055 & 391.1976 & FPQ & $\alpha_{\mathrm{S} 2 \text {-casein } \mathrm{f}(92-94)}$ & l \\
\hline & 446.5737 & 1337.6808 & HIQKEDVPSER & $\alpha_{\mathrm{S} 1}$-casein $\mathrm{f}(80-90)$ & l \\
\hline & 552.2430 & 552.2227 & DAYPS & $\alpha_{\mathrm{S} 1}$-casein $\mathrm{f}(157-161)$ & $\begin{array}{l}\text { Precursor of antioxidant } \\
\text { peptides }\end{array}$ \\
\hline & 680.3035 & 680.2886 & DAYPSGA & $\alpha_{\mathrm{S} 1}$-casein $\mathrm{f}(157-163)$ & $\begin{array}{l}\text { Precursor of antioxidant } \\
\text { peptides }\end{array}$ \\
\hline
\end{tabular}

$A C E$ angiotensin converting enzyme, DPP IV dipeptidyl peptidase IV

${ }^{\text {a }}$ Monoisotopic mass

${ }^{\mathrm{b}} \mathrm{Lx}$ indicates leucine or isoleucine

${ }^{\mathrm{c}}$ Potential bioactivities were achieved from the BIOPEP database

The free tyrosine standard showed an $\mathrm{ABTS}^{+}$radical scavenging activity of $124.7 \pm 12.3 \mathrm{mg}$ of vitamin C.mmol ${ }^{-1}$ of amino acid, which resulted in an $\mathrm{ABTS}^{+}$ value of $274.3 \mathrm{mg}$ of vitamin $\mathrm{C}$ per $2.2 \mathrm{mmol}$ of tyrosine. Considering that the $\mathrm{ABTS}^{+}$ radical scavenging activity of the fraction $\mathrm{F} 2$ was $303.1 \mathrm{mg}$ of vitamin C.L ${ }^{-1}$ of milk, we concluded that the $90 \%$ of the $\mathrm{ABTS}^{+}$radical scavenging activity of this fraction is due to the presence of free tyrosine. Free tyrosine also accounted for the $36.5 \%$ of the total hydroxyl radical scavenging activity of this fraction. Tyrosine is an aromatic amino acid, which is known for its antioxidant activity. The antioxidant properties of tyrosine is due to the presence of the phenolic moiety (aromatic ring with a hydroxyl group), which makes tyrosine a good scavenger of free radicals and metal chelator (Pihlanto 2006). Two additional peptides (LSH and GP), which contained amino acids able to scavenge hydroxyl radical may account for the remaining scavenging capacity 
Table 6 Antioxidant properties of pure amino acids

\begin{tabular}{|c|c|c|c|}
\hline Amino acids ${ }^{a}$ & $\begin{array}{l}\text { ABTS radical scavenging } \\
\text { mg vitamin } \mathrm{C}^{-\mathrm{mmol}^{-1}} \\
\text { amino acid }\end{array}$ & $\begin{array}{l}\text { Hydroxyl radical scavenging } \\
\text { mg vitamin } \mathrm{C}^{-\mathrm{mmol}^{-1}} \\
\text { amino acid }\end{array}$ & $\begin{array}{l}\text { Inhibition of lipid peroxidation } \\
\% \text { of inhibition }{ }^{\text {b }}\end{array}$ \\
\hline Trp & $219.2 \pm 5.9 \mathrm{a}$ & $211.1 \pm 3.1 \mathrm{a}$ & $31.7 \pm 1.1 \mathrm{a}$ \\
\hline Tyr & $124.7 \pm 3.8 b$ & $769.7 \pm 9.5 b$ & $4.9 \pm 0.2 b$ \\
\hline Cys & $162.5 \pm 4.4 \mathrm{c}$ & $766.4 \pm 8.7 b$ & n.d. \\
\hline Met & n.d. & $450.9 \pm 6.4 \mathrm{c}$ & $11.3 \pm 0.8 \mathrm{c}$ \\
\hline Thr & n.d. & $64.1 \pm 2.1 \mathrm{~d}$ & n.d. \\
\hline Pro & n.d. & $59.1 \pm 3.4 d$ & n.d. \\
\hline His & n.d. & $55.3 \pm 2.8 \mathrm{~d}, \mathrm{e}$ & $80.3 \pm 2.3 \mathrm{~d}$ \\
\hline Arg & n.d. & $39.4 \pm 1.4 \mathrm{e}$ & $13.8 \pm 1.1 \mathrm{c}$ \\
\hline Lys & n.d. & n.d. & n.d. \\
\hline Asp & n.d. & n.d. & n.d. \\
\hline Glu & n.d. & n.d. & n.d. \\
\hline Phe & n.d. & $165.6 \pm 8.3 \mathrm{f}$ & $91.4 \pm 5.6 \mathrm{e}$ \\
\hline Leu & n.d. & n.d. & n.d. \\
\hline Ile & n.d. & n.d. & n.d. \\
\hline Gly & n.d. & n.d. & n.d. \\
\hline Val & n.d. & n.d. & n.d. \\
\hline Ala & n.d. & n.d. & n.d. \\
\hline Ser & n.d. & $188.1 \pm 7.3 \mathrm{~g}$ & $50.3 \pm 1.7 \mathrm{f}$ \\
\hline
\end{tabular}

Data are means $\pm \mathrm{SD}(n=3)$. Values in the same columns with different lowercase letters are significantly different (Tukey's test; $P<0.05$ )

n.d. not detected activity

${ }^{\text {a }}$ Three-letter codes

${ }^{\mathrm{b}}$ Percentage of inhibition referred to a control reaction without amino acids (set as $100 \%$ of peroxidation). Amino acids were tested at concentration of $2 \mathrm{mmol} \cdot \mathrm{L}^{-1}$

and lipid peroxidation inhibitory activity of the fraction F2. The peptide LSH contained the amino acids serine and histidine, which displayed hydroxyl radical scavenging capacity and strong lipid peroxidation inhibitory activity (Table 6). The dipeptide GP is of particular interest because it displayed multifunctional properties (Table 4).

Fraction F3 contained some peptides with previously demonstrated radical scavenging activity, which can explain the high value of $\mathrm{ABTS}^{+}$and hydroxyl radical scavenging activity found in this fraction. The $\alpha_{\mathrm{S} 1}$-casein-derived peptide YPEL (146-149) demonstrated radical scavenger activity against DPPH, superoxide anion and hydroxyl radicals (Suetsuna et al. 2000). The presence of the tyrosine residue seems to be very important for the antioxidant properties of the peptide YPEL since its deletion from the sequence halves the radical scavenging activity (Suetsuna et al. 2000). This peptide also gave an intense signal in the MS spectra suggesting that it may be present in high amounts in the fraction F3. The tetrapeptide VRYL $\left(\alpha_{\mathrm{S} 2}\right.$-casein 205-208) forms part of the antioxidant peptide PYVRYL, derived from ovine casein hydrolysate (López-Expósito et al. 2007). The sequence RYL played an important role in the activity since it still showed antioxidant 
activity (De Gobba et al. 2014a). The peptide AVPYPQ ( $\beta$-casein 177-182) is a precursor of two well-known antioxidant peptides, namely, VPYPQ and PYPQ, identified in human milk submitted to gastrointestinal digestion (Raikos and Dassios 2014; Hernández-Ledesma et al. 2007). The domain PYPQ is primary in determining their antioxidant properties. However, the peptide VPYPQ showed a higher antioxidant activity than the peptide PYPQ.

This fraction also showed the best lipid peroxidation inhibitory activity. It contained the free amino acid phenylalanine, which had strong inhibitory activity towards lipid peroxidation (Table 6). This compound is therefore expected to be the primary contributor to the lipid peroxidation inhibitory activity of fraction F3.

Tryptophan is a potent radical scavenger, which contains an indole group that is involved in the stabilization of the tryptophan radical through resonance or delocalization of the unpaired electron (Pihlanto 2006). Tryptophan in fraction F5 was quantified resulting in a value of $1.3 \pm 0.1$ mmol. $\mathrm{L}^{-1}$ of milk. The free tryptophan standard showed an $\mathrm{ABTS}^{+}$radical scavenging activity of $219.2 \pm 16.1 \mathrm{mg}$ of vitamin $\mathrm{C}_{\mathrm{mmol}}{ }^{-1}$ of amino acid, which corresponded to a value of $285 \mathrm{mg}$ vitamin $\mathrm{C}$ per $1.3 \mathrm{mmol}$ of tryptophan. Considering that the $\mathrm{ABTS}^{+}$radical scavenging activity of the fraction F5 was $450 \mathrm{mg}$ of vitamin C.L $\mathrm{L}^{-1}$ of milk, tryptophan accounted for the $63.3 \%$ of the $\mathrm{ABTS}^{+}$radical scavenging activity in this fraction. Based on the data in Tables 3 and 6 , free tryptophan also accounted for the $59.9 \%$ of the hydroxyl radical scavenging activity of fraction F5. Additional peptides with potential radical scavenging activity were found in the fraction F5. For example, the peptides DAYPSGA ( $\alpha_{\mathrm{S} 1}$-casein 157$163)$ and DAYPS ( $\alpha_{\mathrm{S} 1}$-casein 157-163) are precursors of the antioxidant peptide AYPS (De Gobba et al. 2014b). Interestingly, this last peptide was identified, after casein hydrolysis, in a fraction with high antioxidant activity together with the peptides RYPS and SRYPS, suggesting that the sequence YPS could be primary for the antioxidant properties of these peptides. These peptides (DAYPSGA and DAYPS) contained the amino acid tyrosine which displayed strong ABTS and hydroxyl radical scavenging capacities, and amino acids proline and serine were active against the hydroxyl radical (Table 6). Several antioxidative peptides contain the sequence YL or YI in their structure such as the tripeptides YYL, YLY, YYI, YIY (Saito et al. 2003) and RYL (De Gobba et al. 2014a) as well as the longer peptides YIPIQY, FALPQYLK, GYLEQ, YLKT and PYVRYL (De Gobba et al. 2014b; López-Expósito et al. 2007). The amino acids phenylalanine and histidine played an important role in the lipid peroxidation inhibitory activity of the peptides (De Gobba et al. 2014a). Therefore, the peptides present in fraction F5 containing these amino acids could be considered the major contributor to the lipid peroxidation inhibitory activity of this fraction. The peptides FPQ $\left(\alpha_{\mathrm{S} 1}\right.$-casein $\left.92-94\right)$ and HQGLPQ $\left(\alpha_{\mathrm{S} 1}\right.$-casein 8 -13) also gave very intense peak in the MS spectra (Fig. 3), suggesting that they could be present at high concentration in fraction F5.

\subsection{Milk proteins as a carrier for the delivery of antioxidant compounds in the gastrointestinal tract}

Various evidence suggests that oxidative stress is closely associated with the onset and progression of several chronic diseases (Willcox et al. 2004). Therefore, it is generally speculated that antioxidants in the diet can be helpful in counteracting the onset of these diseases. However, the link between in vitro and in vivo antioxidant capacities has not 
been clearly established. With regard to this, despite the large number of in vitro studies reporting the antioxidant activity of bioactive peptides, the in vivo effect of milkderived antioxidant peptides on human health remains unclear (Power-Grant et al. 2013).

The gastrointestinal tract is constantly exposed to reactive oxygen species, from the diet or generated in the gastrointestinal tract itself. Reactive radical species can derive from dietary iron, which in the gastric environment (i.e. in presence of oxygen, acidic $\mathrm{pH}$ and $\mathrm{H}_{2} \mathrm{O}_{2}$ ) may promote Fenton reaction generating superoxide anion and hydroxyl radicals (Halliwell et al. 2000). Reactive oxygen species in the gut can initiate, in the presence of transition metals, the lipid peroxidation of dietary poly-unsaturated fatty acids, resulting in the production of lipid hydroperoxides and advanced lipoxidation end products, which can be further absorbed and involved in the pathogenesis of some cardiovascular diseases (Tagliazucchi et al. 2010). In addition, dietary heme proteins are powerful pro-oxidant which can initiate gastric lipid peroxidation (Tagliazucchi et al. 2010). Indeed, diet can also be a source of lipid hydroperoxide, lipo-oxidation end products and hydrogen peroxide (Halliwell et al. 2000). An additional source of free radical rises from the activation of immune cells naturally present in the gastrointestinal tract by diet-derived bacteria and toxins (Halliwell et al. 2000). Severe oxidative stress in the gastrointestinal tract has been involved in the pathogenesis of colorectal cancer and in inflammation-based gastrointestinal tract diseases (Kim et al. 2012).

Bioactive peptides might exert direct protective effects in the gastrointestinal tract by scavenging reactive oxygen species and reducing the oxidative stress. The gastrointestinal tract is in contact with digested food proteins and therefore, with a significant amount of food derived peptides. With this view, milk proteins can be considered as a carrier for the delivery of antioxidant compounds in the gastrointestinal tract. In milk, antioxidant amino acids and peptides are preserved from oxidation and degradation since they are encrypted in the protein sequences. The simultaneous action of intestinal proteases determines a slow and continuous release of antioxidant peptides and amino acids from the parent proteins protecting the gastrointestinal tract itself from the oxidative damage and the onset of oxidative diseases. The low bioavailability of protein-derived bioactive peptides supports this hypothesis, suggesting that, at least in part, the physiological effect of bioactive peptides on the organism could derive from a biological effect in the gastrointestinal tract.

\section{Conclusion}

Our results indicate that the amino acids tyrosine and tryptophan, released during in vitro gastrointestinal digestion and some identified tyrosine-containing peptides, were majorly responsible for the radical scavenging activity of digested milk, whereas phenylalanine and histidine-containing peptides played a crucial role in the lipid peroxidation inhibitory capacity of digested milk. Many previous studies were carried out with the aim to identify antioxidant peptides released from bovine milk after proteases treatment. Despite numerous antioxidant peptides having been identified, it is likely that they lack a real physiological systemic effect because they can be further degraded by membrane-bound amino-peptidase in the intestine or they can be poorly absorbed due to their size and thus possibly are no longer available to elicit a biological 
response. However, we propose that the biological activity of these antioxidant compounds can be relevant for the gastrointestinal tract. In our view, antioxidant compounds can be slowly and continuously released from milk proteins protecting the gastrointestinal tract itself from oxidative damage.

Further studies should be carried out to elucidate the in vivo contribution of these antioxidant compounds to the antioxidant status of the gastrointestinal tract after milk consumption.

\section{Compliance with ethical standards}

Conflict of interest Davide Tagliazucchi, Ahmed Helal, Elena Verzelloni, and Angela Conte declare that they have no conflict of interest.

\section{References}

Adler-Nissen J (1979) Determination of the degree of hydrolysis of food protein hydrolysates by trinitrobenzensulfonic acid. J Agric Food Chem 27:1256-1262

Ajibola CF, Fashakin JB, Fagbemi TN, Aluko RE (2011) Effect of peptide size on antioxidant properties of African yam bean seed (Sphenostylis stenocarpa) protein hydrolysate fractions. Int J Mol Sci 12:66856702

Boutrou R, Henry G, Sanchez-Rivera L (2015) On the trail of milk bioactive peptides in human and animal intestinal tracts during digestion: a review. Dairy Sci Technol 95:815-829

Bu G, Luo Y, Chen F, Liu K, Zhu T (2013) Milk processing as a tool to reduce cow's milk allergenicity: a mini review. Dairy Sci Technol 93:211-223

Cervato G, Cazzola R, Cestaro B (1999) Studies on the antioxidant activity of milk caseins. Int J Food Sci Nutr 50:291-296

Clausen MR, Skibsted LH, Stagsted J (2009) Characterization of major radical scavenger species in bovine milk through size exclusion chromatography and functional assays. J Agric Food Chem 57:2912-2919

De Gobba C, Espejo-Carpio FJ, Skibsted LH, Otte J (2014a) Antioxidant peptides from goat milk protein fractions hydrolysed by two commercial proteases. Int Dairy J 39:28-40

De Gobba C, Tompa G, Otte J (2014b) Bioactive peptides from caseins released by cold active proteolytic enzymes from Arsukibacterium ikkense. Food Chem 165:205-215

Dei Più L, Tassoni A, Serrazanetti DI, Ferri M, Babini E, Tagliazucchi D, Gianotti A (2014) Exploitation of starch industry liquid by-product to produce bioactive peptides from rice hydrolyzed proteins. Food Chem 55:199-206

Del Mar Contreras M, Hernández-Ledesma B, Amigo L, Martín-Álvarez PJ, Recio I (2011) Production of antioxidant hydrolyzates from a whey protein concentrate with thermolysin: optimization by response surface methodology. LWT Food Sci Technol 44:9-15

Del Rio D, Rodriguez-Mateos A, Spencer JPE, Tognolini M, Borges G, Crozier A (2013) Dietary (poly)phenolics in human health: structures, bioavailability, and evidence of protective effects against chronic diseases. Antioxid Redox Signal 18:1818-1892

Frank MP, Power RW (2007) Simple and rapid quantitative high-performance liquid chromatographic analysis of plasma amino acids. J Chromatogr B Anal Technol Biomed Life Sci 852:646-649

Halliwell B, Zhao K, Whiteman M (2000) The gastrointestinal tract: a major site of antioxidant action? Free Radic Res 33:819-830

Helal A, Tagliazucchi D, Verzelloni E, Conte A (2014) Bioaccessibility of polyphenols and cinnamaldehyde in cinnamon beverages subjected to in vitro gastro-pancreatic digestion. J Funct Foods 7:506-516

Hernández-Ledesma B, Dávalos A, Bartolomé B, Amigo L (2005) Preparation of antioxidant enzymatic hydrolysates from $\alpha$-lactalbumin and $\beta$-lactoglobulin identification of active peptides by HPLC-MS/MS. J Agric Food Chem 53:588-593

Hernández-Ledesma B, Quiros A, Amigo L, Recio I (2007) Identification of bioactive peptides after digestion of human milk and infant formula with pepsin and pancreatin. Int Dairy J 17:42-49

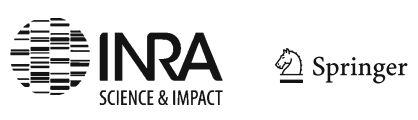


Kim YJ, Kim EH, Hahm KB (2012) Oxidative stress in inflammation-based gastrointestinal tract diseases: challenges and opportunities. J Gastroenterol Hepatol 27:1004-1010

López-Expósito I, Quirós A, Amigo L, Recio I (2007) Casein hydrolysates as a source of antimicrobial, antioxidant and antihypertensive peptides. Lait 87:241-249

Petrat-Melin B, Andersen P, Rasmussen JT, Poulsen NA, Larsen LB, Young JF (2015) In vitro digestion of purified $\beta$-casein variants $A^{1}, A^{2}, B$, and $I$ : effects on antioxidant and angiotensin-converting enzyme inhibitory capacity. J Dairy Sci 98:15-26

Petrat-Melin B, Kristiansen GH, Le TT, Poulsen NA, Larsen LB, Young JF (2016) In vitro gastrointestinal digestion of purified bovine $\mathrm{K}$-casein variants $\mathrm{A}, \mathrm{B}$, and $\mathrm{E}$ : effects on antioxidant and angiotensin 1converting enzyme inhibitory capacity. Int Dairy J 57:44-51

Picariello G, Miralles B, Mamone G, Sánchez-Rivera L, Recio I, Addeo F, Ferranti P (2015) Role of intestinal brush border peptidases in the simulate d digestion of milk proteins. Mol Nutr Food Res 59:984-956

Pihlanto A (2006) Antioxidative peptides derived from milk protein. Int Dairy J 16:1306-1314

Power-Grant O, Jakeman P, FitzGerald RJ (2013) Antioxidative peptides: enzymatic production, in vitro and in vivo antioxidant activity and potential applications of milk derived antioxidative peptides. Amino Acids 44:797-820

Power-Grant O, McCormack WG, Ramia De Cap M, Amigo-Benavent M, FitzGerald RJ, Jakeman P (2016) Evaluation of the antioxidant capacity of a milk protein matrix in vitro and in vivo in women aged 50-70 years. Int J Food Sci Nutr 67:325-334

Raikos V, Dassios T (2014) Health-promoting properties of bioactive peptides derived from milk proteins in infant food: a review. Dairy Sci Technol 94:91-101

Re R, Pellegrini N, Proteggente A, Pannala A, Yang M, Rice-Evans C (1999) Antioxidant activity applying an improved ABTS radical cation decolorization assay. Free Radic Biol Med 26:1231-1237

Saito K, Jin DH, Ogawa T, Muramoto K, Hatakeyama E, Yasuhara T, Nokihara K (2003) Antioxidative properties of tripeptide libraries prepared by the combinatorial chemistry. J Agric Food Chem 51:36683674

Suetsuna K, Ukeda H, Ochi H (2000) Isolation and characterization of free radical scavenging activities peptides derived from casein. J Nutr Biochem 11:128-131

Tagliazucchi D, Verzelloni E, Conte A (2010) Effect of dietary melanoidins on lipid peroxidation during simulated gastric digestion: their possible role in the prevention of oxidative damage. J Agric Food Chem 58:2513-2519

Tagliazucchi D, Martini S, Bellesia A, Conte A (2015) Identification of ACE-inhibitory peptides from Phaseolus vulgaris after in vitro gastrointestinal digestion. Int J Food Sci Nutr 66:774-782

Willcox JK, Ash SL, Catignani GL (2004) Antioxidants and prevention of chronic disease. Crit Rev Food Sci Nutr 44:275-295 